\title{
ANALYSIS OF SEWAGE SLUDGE THERMAL TREATMENT METHODS IN THE CONTEXT OF CIRCULAR ECONOMY
}

\author{
Anna Tsybina ${ }^{1, *}$ and Christoph Wuensch ${ }^{2}$ \\ ${ }^{1}$ Environmental Protection Department, Perm National Research Polytechnic University, Komsomolsky av. 29, 614990 Perm, Russia \\ ${ }^{2}$ Institute of Waste Management and Circular Economy, Dresden Technical University, Pratzschwitzer Str. 15, 01796 Pirna, Germany
}

Article Info:
Received:
17 January 2018
Revised:
7 May 2018
Accepted:
20 June 2018
Available online:
30 June 2018
Keywords:
Sewage sludge
Circular economy
Incineration
Gasification
Pyrolysis

Article Info:

17 January 2018

20 June 2018

Available online:

30 June 2018

Keywords:

ircular ecol

Pyrolysis

\begin{abstract}
As of now, the most common applications of sewage sludge treatment and disposal methods globally are in agriculture and deposition in landfills. In particular, landfill disposal causes problems associated with environmental pollution, as well as problems caused by the loss of the chance to recover energy and nutrients out of the sewage sludge. The critical content of hazardous substances in the sewage sludge makes its use in agriculture as fertilizer questionable. Thermal treatment methods offer a solution to these problems because energy can be recovered and used, some hazardous materials can be destroyed or removed, and valuable nutrients such as phosphorus can be utilized in the generated products or recovered from these products. In a first step, the objective and scope of the study and especially the important characteristics of the circular economy when considering sewage sludge treatment possibilities is described. Based on these characteristics for the three investigated thermal treatment methods - incineration, gasification and pyrolysis - a comparative analysis on the basis of a suggested set of criteria (1. cost, 2. energy efficiency, 3 . nutrient recovery, 4. product market value and 5. flexibility) was carried out. In the result, incineration of sewage sludge performs best in terms of treatment costs, energy efficiency, nutrient recovery, and flexibility concerning feedstock dry matter content. Pyrolysis performs best in terms of market value of the generated products and flexibility regarding plant size.
\end{abstract}

\section{INTRODUCTION}

Due to the rapid development of the pharmaceutical industry and the increasing consumption of emerging contaminants such as personal care products, the composition of pollutants contained in municipal wastewater has changed over the last years. The composition now includes organic compounds, oil products, suspended particles, heavy metals, pathogenic substances and chemical contaminants. At the same time, conventional wastewater treatment methods have remained unchanged for decades in many cases. Mechanical and biological treatment methods are most often used for cleaning municipal wastewater, since they are most effective for removing the above-mentioned contaminants. The conventional municipal wastewater treatment scheme leads to the generation of a large amount of paste-like waste - so-called wastewater sludge or sewage sludge.

Statistical data collected all over the world shows that in general the amount of sewage sludge strongly depends on the total population of a country as the specific sewage sludge production per person per year is more or less stable at the level of $25 \mathrm{~kg}$ of dry substance (UN-HABITAT, 2008). Thus, the expanding population in a number of developing countries such as China and India results in yearly increases in sewage sludge volume. At the same time, higher-income countries may continuously improve infrastructure and wastewater treatment technologies, producing increasingly larger masses of sewage sludge per country. Urbanization processes that occur in both developing and developed countries lead to increases in the volumes of water used in municipal economies; these processes also result in a rise in total sewage sludge production.

Sewage sludge is a large-tonnage waste with some specific characteristics caused by its high water content, which hampers its final disposal. Sewage sludge contains considerable amounts of nutrients, such as nitrogen and phosphorus, but also a number of harmful contaminants, e.g. inorganic pollutants: toxic heavy metals such as lead, mercury, cadmium, copper and uranium; as well as organic toxins such as dioxin, polychlorinated biphenyls, perfluorinated surfactants, pharmaceutical residues, pathogens and others (Erikson et al., 2007) that limit its application as a fertilizer. Sewage sludge has high water content, and 
the moisture it contains is presented in several different forms, including free water, pore water and colloid moisture (bound water) (Deng et al., 2011). The latter in particular makes sewage sludge difficult to dewater. Dry solid content of sewage sludge after a wastewater treatment plant is only $1-3 \%$, then the thickening process enlarges this parameter to $3-5 \%$, and mechanical dewatering results in a maximum of $20-30 \%$ dry solid content. Only with the use of thermal drying can sewage sludge dry solid content be increased to approximately $92 \%$ (Stasta et al., 2006; Uggetti et al., 2009).

Until now, the most commonly used sewage sludge treatment and disposal methods globally are its use in agriculture after the thickening process, production and use of compost after mechanical dewatering, and deposition in landfills (Stasta et al., 2006). Even in some European countries, landfilling of sewage sludge is still the primary method of its disposal (see Figure 1). The disposal of sewage sludge in landfills has a number of significant drawbacks, including the necessity for sizeable lands; negative aesthetic impact; pollution of soil, surface and groundwater; emissions of heavy metals into the environment; potential risk of negative impact due to the presence of pathogenic microflora; and loss of energy and material waste potential - the latter mainly because of the irreparable loss of valuable nutrients. Thus, the problems associated with the landfilling of sewage sludge can be brought together into two groups - firstly, problems associated with environmental pollution, and secondly, problems caused by the lost potential to recover energy and/or nutrients out of the sewage sludge.

According to the integrated waste management hierarchy presented in the Directive 2008/98/EC on waste (the so-called Waste Framework Directive), landfilling is the least preferable means of waste treatment (Directive 2008/98/EC, 2008). If it is impossible to prevent generation of a certain type of waste at all, it is advisable to ensure reuse of the waste, followed by the use of its material or energy potential. An alternative to landfilling can be the use of sewage sludge in agriculture as a fertilizer, or for the restoration of disturbed lands, either pre-dried or composted. This ensures recovery of nutrients contained in sewage sludge to the natural metabolic cycles but does not solve the problem of environmental pollution by harmful substances. Some of these contaminants can be removed by means of thermal treatment methods that allow not only significant reduction of the negative environmental impact of untreated sewage sludge but also utilization of its energy potential (Houillon and Jolliet, 2005).

In recent years both landfilling of sewage sludge and its use in agriculture are being significantly reduced in EU member states due to the restrictions of respective pieces of EU legislation (Lundin et al., 2004; Smol et al., 2015; Valderrama et al., 2013).

Consequently, scientific research aimed at evaluating efficiency and searching for the optimal technological parameters for processes of sewage sludge thermal treatment have become in demand. However, at present, the use of thermal methods for the processing of sewage sludge is practiced only in a few countries around the world (Raheem et al., 2018; Pavlik et al., 2016).

The reasons for limited application of thermal treatment methods and such a wide use of sewage sludge landfilling are primarily economic. In this paper, an attempt has been made to prove the efficiency of the application of sewage sludge thermal treatment methods on a broader scale than an individual economic entity or a waste recycling plant. To do so, the authors have analyzed three wide-

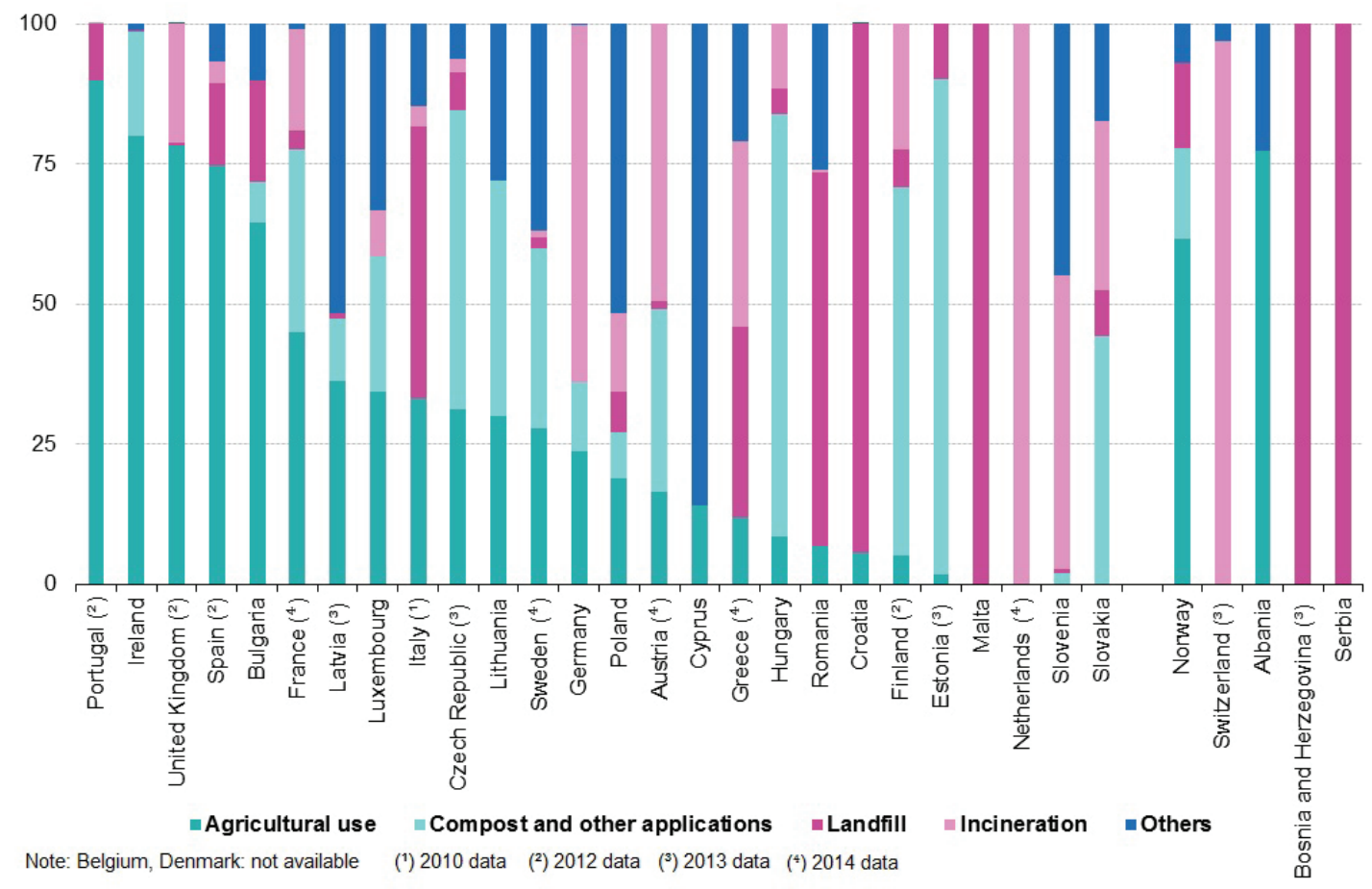

FIGURE 1: Municipal sewage sludge disposal by type of treatment in Europe, 2015 (Eurostat, 2015). 
ly known sewage sludge thermal utilization methods in the circular economy context, which implies maximum extended retention of product added value and exclusion of waste generation where possible.

\section{METHODOLOGICAL APPROACH}

\subsection{The objective and the scope of the study}

The main objective of the study was to evaluate the efficiency of the use of thermal sewage sludge treatment methods within the framework of a circular economy. The subject matter of the study is the three most widely used thermal waste treatment methods, namely incineration, gasification and pyrolysis. The scope of the study performed was the comparative assessment of these three methods applied for sewage sludge treatment on the basis of the concept of a circular economy.

In order to achieve the main objective, the following tasks were formulated:

- To examine the concept of circular economy in order to define the place and the role of waste management within it;

- To analyze the model of circular economy, defining its main characteristics and differences from the conventional "linear" economy model;

- To specify the main characteristics of a circular economy with regard to the subject matter of the study and to draw up a set of evaluation criteria for the assessment of sewage sludge thermal treatment methods in the context of circular economy;

- To carry out a comparative analysis of the considered sewage sludge thermal treatment methods on the basis of the suggested set of criteria and to select the most advantageous method.

\subsection{The concept of circular economy and its main characteristics}

The circular economy concept was chosen as a basis of analysis since it is one of the priority concepts of economic development underlying the current European policy in the field of environmental protection. To ensure the transition to a circular economy, the European Commission has developed an Action Plan for the Circular Economy, in which four key action areas have been defined (European Commission, 2015). In the case of sewage sludge, the study should be focused only on two key areas of this action plan: waste management and secondary raw materials.

Waste management and the recovery of secondary raw materials play a central role in a circular economy. As it is specifically indicated in the action plan, the EU waste hierarchy should be applied so that the options that deliver the best environmental outcome are encouraged. Biological materials are to be returned to the natural metabolic cycles after the necessary pre-treatment, such as composting or digestion. The waste that cannot be prevented or recycled is to be used for the recovery of its energy potential, which is considered preferable to landfilling. The introduction of secondary raw materials into the economy is considered a positive factor that extends the security of supply. This would mean fewer risks connected to exposure to volatile raw material prices, and also fewer risks connected to unstable supply because of sudden natural disasters or changes in geopolitical situations. Nutrients are indicated as an especially important category of the secondary raw materials produced out of waste (Ellen McArthur Foundation, 2013).

When considering the transition to a circular economy concept in general, the application of systems thinking is extremely important. Transformation of waste into secondary raw materials ensures reorganization of linear material flows of a conventional economy into circular flows, where waste generation is excluded. Systems thinking should be taken into account when evaluating the efficiency of different sewage sludge treatment methods.

Another important feature of a circular economy arises from one of the main subjects it addresses, namely waste, which can contain harmful or hazardous pollutants. In the case of sewage sludge, there is a risk associated with possible negative impacts to the environment by pathogenic substances, endocrine disrupters, heavy metals and the accumulation of heavy metals in living organisms.

Summarizing the conducted study of circular economy and its basic characteristics, keeping in mind peculiar properties of the considered type of waste, sewage sludge, the following features demonstrating the circular nature of the given sector of economic activity can be singled out:

\section{Exclusion of waste disposal in landfills;}

Exclusion of pollutant emissions into the environment;

Reuse/recycling/energy recovery out of the waste;

- Reduced input of primary natural resources, fossil fuels and electricity in comparison with the traditional model of the economy;

- Application of systems thinking, when at individual stages of a product life cycle, different enterprises, service providers or even allied industries are involved;

- Exclusion of accumulation of hazardous substances in the environment and living organisms.

The selected characteristics of a circular economy will be considered in further detail in the analytical part of the paper. An overview of the highlighted important aspects of the circular economy and some known examples of their implementation with sewage sludge (SS) as an object of treatment, as well as the associated risks, are presented in Figure 2.

\subsection{Criterion model for the assessment of sewage sludge thermal treatment methods}

A preliminary rough examination of sewage sludge treatment methods, performed above, shows that thermal treatment methods meet a number of requirements for the handling of waste within the framework of a circular economy. These methods allow energy to be recovered from waste, natural resources (such as land) to be saved, and valuable by-products to be gained for use as raw materials or marketable products in various industries (Cieślik and Konieczka, 2017; Vadenbo et al., 2014). In order to arrange and specify this information, it was necessary to carry out 


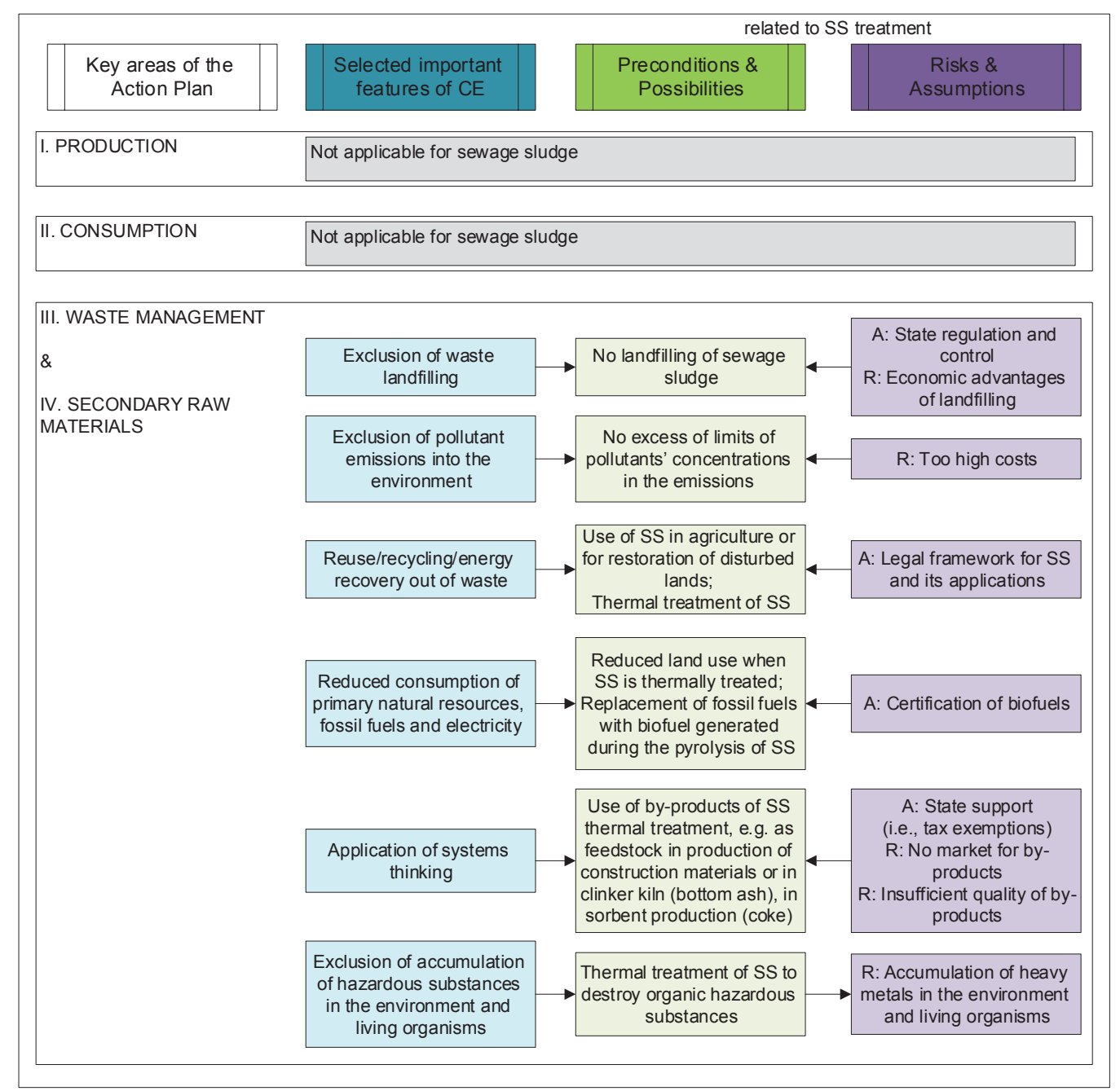

FIGURE 2: Important characteristics of a circular economy when considering sewage sludge treatment possibilities. Abbreviations: A: assumptions; R: risks; SS: sewage sludge.

a comparative analysis of thermal sewage sludge treatment methods in the context of a circular economy.

The comparative analysis was carried out on the basis of a criterion model. The subject of analysis was three thermal methods of sewage sludge treatment - incineration, gasification and pyrolysis.

When developing the criteria, a number of important aspects of circular economy were taken into account, such as the minimum possible energy input in waste treatment processes (energy efficiency), the maximum retention of value in the economy, removal of pollutants from the material cycle, and the possibility for the recovery of nutrients contained in the waste (Alvarenga et al., 2015; Li et al., 2017). In addition, since sewage sludge thermal treatment methods are considered more costly and more technically complex than the disposal of sewage sludge at landfills or its application in agriculture, the criteria also concern the cost-benefits and technical feasibility of using a particular method. The purpose of the analysis was to identify the sewage sludge thermal treatment method which was the most preferable in the context of a circular economy, and also the most economically and technically feasible.

The following five criteria were developed for carrying out the comparative analysis:

1. Costs of waste treatment using the selected method;

2. Energy efficiency of the processing scheme;

3. Recovery of nutrients;

4. Market value of products/by-products;

5. Flexibility when applying the method.

When performing the analysis, assessments for individual criteria were given in the ranges of the corresponding units. For example, costs were assessed in euros per ton of treated dry material per year, energy balance in megawatts $(\mathrm{MW})$. After the comparative analysis was performed, a rating of the three thermal treatment meth- 
ods was assigned on a three-level scale "Best - Average - Worst".

\section{COMPARATIVE ANALYSIS OF THERMAL SEWAGE SLUDGE TREATMENT METHODS}

\subsection{Costs of waste treatment using the selected method}

Costs of waste treatment using a particular thermal method differ markedly from country to country. Moreover, when comparing the expenditure for waste treatment with the use of different methods, it is necessary to take into account a number of technical aspects, such as:

- The type of equipment used (facilities designed specifically for the processing of sewage sludge, or standard equipment used in other industries);

- Treatment of the certain type of waste exclusively or co-processing of sewage sludge and other wastes such as municipal solid waste.

When this study was conducted, the literature data on the results of thermal treatment of sewage sludge only (no co-processing with other types of waste) with the use of the equipment specifically designed for this type of waste was analyzed.

\subsubsection{Incineration}

The following financial numbers for incinerating sewage sludge include the thermal drying process at the incineration plant as well as the flue gas cleaning to reach European emissions limits (usually based on dry sorption and a bag filter).

The biggest known fluidized bed incineration plant for sewage sludge in Hong Kong has 4 lines with a capacity of $45,000 \mathrm{Mg} / \mathrm{a}$ dry substance (ds) (for 6.2 million people), and the smallest plant has one line with 2,000 Mg/a dry substance (for 70,000 people).

(Frank and Schröder, 2014) as well as (Glatzer and Friedrich, 2015) report the following financial figures to fluidised bed incineration plants with the capacities of 35,000, 4,000 and 2,000 Mg dry substance/a. The plant with the capacity of $35,000 \mathrm{Mg}$ produces electricity and heat by a steam boiler and a steam turbine with a generator. The smaller plants produce heat only by a thermal oil boiler because the generation of electricity in smaller plants is very inefficient from an economic point of view.

As shown in Table 1, the biggest plant $(35,000 \mathrm{Mg}$ ds/a for approx. 1.2 million people) is, with 157 euros/Mg treated dry substance, much more economically efficient than smaller plants $(2,000 \mathrm{Mg}$ or $4,000 \mathrm{Mg}$ ds/a for 70,000 -
140,000 people) with about 500 euros/Mg ds.

\subsubsection{Gasification}

No comparable data on the specific costs of gasification were found for this paper. However, a general overview of scientific literature allowed the authors to conclude that the specific costs for gasification of sewage sludge significantly exceed the specific costs of incineration and pyrolysis (Mills, 2015; EPA, 2012). This is due to both the high cost of equipment and the complexity of maintaining the gasification process itself.

\subsubsection{Pyrolysis}

When thermally treating sewage sludge with the use of pyrolysis technology, a significant downscaling is possible. (CORDIS, 2017) gives the data on a small-scale pyrolysis plant with the capacity of a maximum $200 \mathrm{Mg}$ of sewage sludge per year. The system thermally dries the dewatered sewage sludge and uses pyrolysis technology to convert it into biochar and gas by-products. To reduce the energy consumption, the energy contained in the sewage sludge is recovered and reused. The pyrolysis syngas is burned in a gas engine, generating heat and electricity that is then used in the system. The waste heat from the gas engine is reused in the dryer. The estimated average costs of the sewage sludge treatment is $400-650$ euros/Mg treated dry substance.

The analysis of another study with a larger installation for the pyrolysis of sewage sludge with a capacity of 155.7 $\mathrm{kg} \mathrm{ds} / \mathrm{h}$, assuming that the operating time of the plant is $7,000 \mathrm{~h} / \mathrm{a}$ (hence the annual capacity is approx. $1,000 \mathrm{Mg}$ ds), shows that, depending on the selected mode (the most costly one is when, after the pyrolysis reactor, the electricity is produced in an externally fired micro gas turbine and organic ranking cycle motor), the maximum specific costs of sewage sludge treatment are 183 euros/Mg ds (Morgano et al., 2016).

It should be emphasized that in order to carry out a comprehensive estimation of expenditures, in addition to the above mentioned technical aspects, a number of other factors that significantly affect the cost of treatment using the selected thermal method should be taken into account, including:

- Costs of land acquisition;

- Operation scale (smaller scale can significantly increase the costs, as shown above);

- Legal requirements for flue gas treatment and pollutants quotas;

- Requirements and possibilities for treatment and dis-

TABLE 1: Economic comparison of different plant sizes for stationary fluidised bed incineration (Glatzer A. and Fiedrich M., 2015; Franck J. and Schroeder L., 2014).

\begin{tabular}{l|c|c|c}
\hline Capacity/throughput & $35,000 \mathrm{Mg} \mathrm{ds} / \mathrm{a}$ & $4,000 \mathrm{Mg} \mathrm{ds} / \mathrm{a}$ & $2,000 \mathrm{Mg} \mathrm{ds} / \mathrm{a}$ \\
\hdashline Capital costs & 35 million Euro & 12 million Euro & 6.6 million Euro \\
\hline Running costs & 5.5 million Euro/a & 1 million & 1 million Euro/a \\
\hline Specific costs * & 157 Euro/Mg ds & 487 Euro/Mg ds & 510 Euro/Mg ds \\
\hline
\end{tabular}

* Specific costs include all the costs related to the certain plant, i.e. capital costs and running costs, calculated per ton of dry substance. 
posal/recovery of ash residues;

Efficiency of energy recovery, and the revenue received for the heat/electricity produced;

- Taxes levied on emissions and subsidies received for thermal treatment (if any);

- Logistics and availability of infrastructure required for the delivery of waste;

- Insurance, administration and personnel costs (IPPC, 2006).

\subsection{Energy efficiency of the processing scheme}

\subsubsection{Incineration}

During the incineration process, combustible material is oxidized and energy is released as thermal energy in the flue gas. Only small amounts of energy (approx. 5\%) are lost by radiation over the surface of the incinerator and the boiler as well as heat in the filtered ashes. In bigger fluidized bed incinerators approx. $80 \%$ of the energy of the flue gas is recovered by a boiler, and the generated steam is used to produce electricity (electrical efficiency up to $20 \%$ ) and heat for the drying of the sewage sludge and for district heating (heat efficiency up to 60\%) (ÖWAV, 2013; Brunner P. and Rechenberger H., 2015). In smaller plants, the generation of steam and the production of electricity are economically inefficient, so only heat is recovered from the flue gas by a thermal oil boiler for the drying of sewage sludge and the generation of some district heating. Table 2 shows energetic data for different plant sizes.

The plants with capacities of 35,000 and $4,000 \mathrm{Mg}$ ds/a produce electricity of 1.4 MW (approx. 11,000 MWh/a) and $0.12 \mathrm{MW}$ (900 MWh/a), respectively. Only the one with the capacity of $35,000 \mathrm{Mg}$ ds/a finally exports, after its own consumption, approx. 0.4 MW (approx. 5,000 MWh/a). The small plant produces no electricity but uses at least the produced energy to cover the heat for drying the sewage sludge.

\subsubsection{Gasification}

During the gasification process organic substances are converted to syngas and the inert material to ash. Gasification is carried out with substoichiometric oxygen and in some cases also with additional external heat. The energy for the thermal drying of mechanically dewatered sewage sludge (75-90\% of dry substance is necessary for the gasification process) is realized by the utilization of the produced syngas. In Germany two plants for the gasification of sewage sludge are in operation. One plant has a capacity of approx. 2,000 Mg ds/a and the other one approx.
4,500 Mg ds/a.

Both plants are based on a two stage gasification process where sewage sludge (dry content $85-95 \%$ ) is conveyed from the silo, together with limestone, to a thermolysis screw feeder. The products, thermolysis gas as well as carbon and ash generated during thermolysis, are conveyed to a fluidized-bed gasifier. In the second stage of gasification, the carbon is converted under substoichiometric conditions into gas, and the long-chain molecules (so-called tar) of the thermolysis gas are cracked. The produced syngas is, after treatment (gas cleaning), used to run a gas engine to generate combined heat and power (Figure 3). Surplus gas can be used in a combustion chamber to generate heat (Sülzle Kopf, 2017).

Based on information from the manufacturer, for a plant with $4,500 \mathrm{Mg}$ ds/a (2.3 MW), electricity of 4,200 MWh/a $(0.6 \mathrm{MW})$ and heat of $5,500 \mathrm{MWh} / \mathrm{a}(0.8 \mathrm{MW})$ can be produced. Operators of wastewater treatment plants (gasifiers are connected to the WWTP) only give information that with the recovered energy, the plants' own consumption for sewage sludge drying and operation of the gasifier can almost be covered. The gasification process, finally, has an almost equal energy balance for the thermal treatment of anaerobically stabilized and mechanically dewatered sewage sludge. No surplus energy can be exported from the process.

\subsubsection{Pyrolysis}

Pyrolysis of sewage sludge is in most cases connected to a final combustion of the pyrolysis gas in an afterburner chamber. In theory it is also possible to treat the pyrolysis gas to run gas engines or gas turbines. Another option is to run the pyrolysis process so as to produce more oil instead of gas. In some applications the produced char out of the pyrolysis step is further used as a product; in other cases the char is incinerated in a second step to directly recover the residual energy, and an inert ash is the final product (EISENMANN, 2017).

In Europe only a small number of plants for sewage sludge pyrolysis are in operation, with two different processes. The first needs an input of sewage sludge with a dry substance of at least $65 \%$ and performs the pyrolysis at $600^{\circ} \mathrm{C}$. The produced bio-char is removed as a product and the pyrolysis gas is incinerated in a combustion chamber at $1,100^{\circ} \mathrm{C}$ (Figure 4). The energy of the produced flue gas is used to heat the pyrolysis reactor and to dry the mechanically dewatered sewage sludge to $65 \%$ dry substance (Greenlife, 2017).

From $500 \mathrm{~kW}$ sewage sludge input, the entire plant (ca-

TABLE 2: Energy balance of different plant sizes for stationary fluidized bed incineration (Franck J., 2015; Franck J. and Schroeder L., 2014; Franck J and Schroeder L, 2015; Glatzer A. and Friedrich M., 2015).

\begin{tabular}{l|c|c|c}
\hline Capacity/throughput & $35,000 \mathrm{Mg} \mathrm{ds} / \mathrm{a}$ & $4,000 \mathrm{Mg} \mathrm{ds} / \mathrm{a}$ & $2,000 \mathrm{Mg} \mathrm{ds} / \mathrm{a}$ \\
\hline Thermal input & $14.5 \mathrm{MW}$ & $1.9 \mathrm{MW}$ & $0.95 \mathrm{MW}$ \\
\hline Energy for drying & $7 \mathrm{MW}$ & $0.7 \mathrm{MW}$ & $0.43 \mathrm{MW}$ \\
\hline Produced electricity & $1.4 \mathrm{MW}$ & - \\
\hline Electricity consumption & $1 \mathrm{MW}$ & $0.11 \mathrm{MW}$ & - \\
\hline Delivered electricity & $0.4 \mathrm{MW}$ & - & - \\
\hline
\end{tabular}




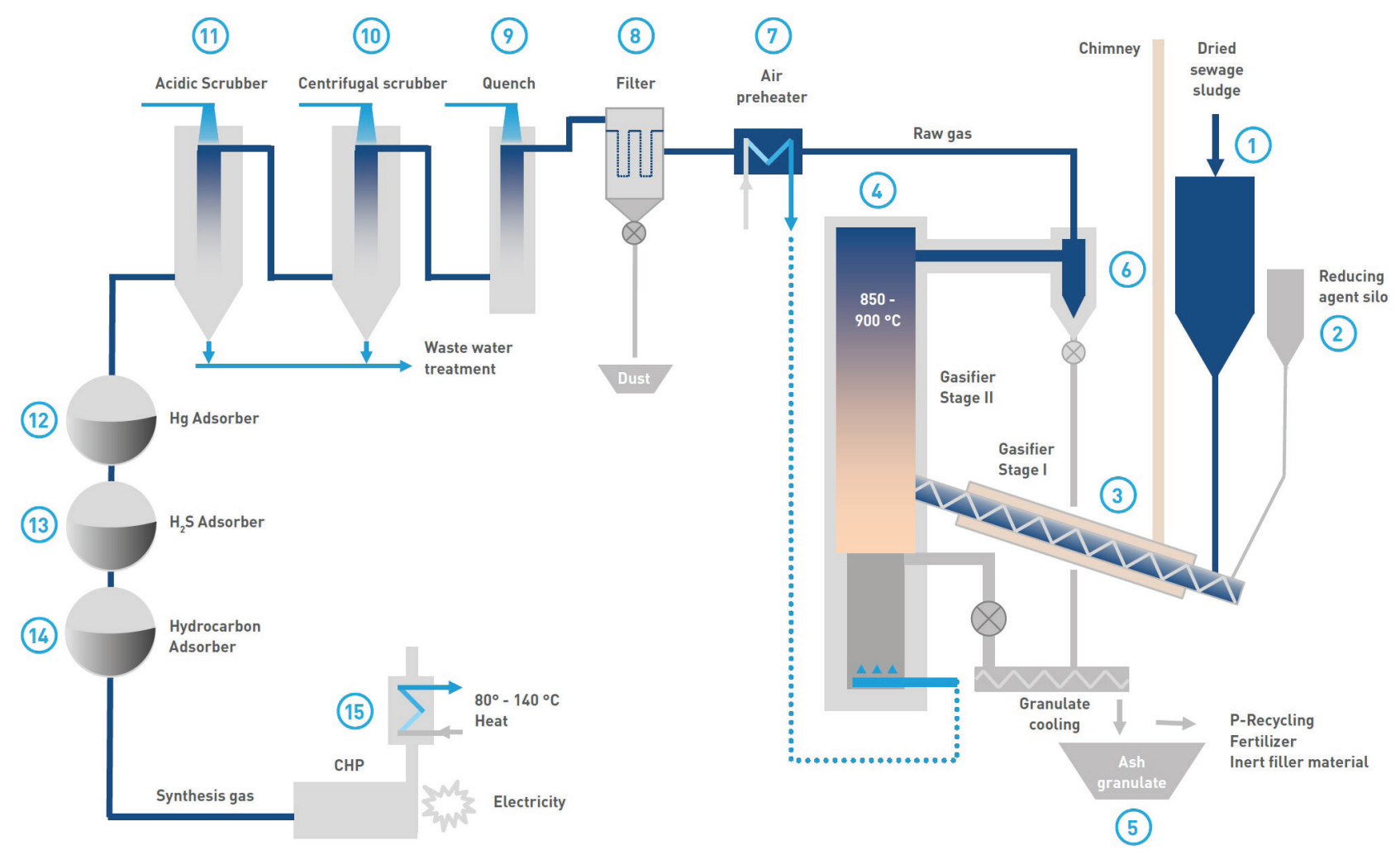

FIGURE 3: KOPF SynGas utilisation process (Sülzle Kopf, 2017).

pacity of $1,000 \mathrm{Mg} / \mathrm{a} \mathrm{ds}$ ) produces about $150 \mathrm{~kW}$ flue gas heat that is used for the heating of the pyrolysis chamber and drying of sewage sludge. The plant is more or less energy self-sufficient but needs an electrical input of approx. $7.5 \mathrm{~kW}$ (an amount which seems to be very small and might concern only the pyrolysis reactor). The product of the process is roughly $500 \mathrm{Mg} / \mathrm{a}$ bio-char (Greenlife, 2017).

The second process is based on the pyrolysis of $90 \%$ dry substance sewage sludge at $300-350^{\circ} \mathrm{C}$ and the combustion of the produced coke at $650^{\circ} \mathrm{C}$. The produced flue gas of the combustion is used to heat the pyrolysis and is then after-burned with the pyrolysis gas at $900^{\circ} \mathrm{C}$. The energy of the produced flue gas of the afterburner chamber is transferred by a thermal oil heat exchanger to the drying of the dewatered sewage sludge (Figure 5). The final product out of the process is inert ash (EISENMANN, 2017).

The plant has a capacity of approx. 4,000 Mg/a ds (approx. 2,000 kW). Small amounts of external fuel in the form of natural gas ( $260 \mathrm{~kW})$ are used to ensure a flue gas temperature that heats the pyrolysis and the afterburner chamber. After energy losses, approx. 2,000 kW of flue gas is produced to dry the dewatered sewage sludge (approx. $21 \%$ ds) to $90 \%$ ds. For this thermal drying, approx. 1,000 kW of additional external thermal energy is necessary (Neumann and Tittesz, 2011; EISENMANN, 2017). No information about the plant's own consumption of electricity is available; based on the size of the plant, $100 \mathrm{~kW}$ is estimated.

Finally, it can be stated that the energy balance of the pyrolysis of sewage sludge is negative. The overall pro- cess, from the drying of the mechanically dewatered sewage sludge to the final treatment of the flue gases, needs more energy than can be recovered out of the process.

\subsection{Recovery of nutrients}

\subsubsection{Incineration}

During the combustion process, organic pollutants, endocrine disruptors and pathogens contained in sewage sludge are destroyed, and volatile heavy metals such as quicksilver are transferred to the flue gas. The nutrients, especially phosphorus, are not transferred in the form of gaseous compounds to the flue gas and are kept in the incinerator ash. In fluidized bed incinerators most of the generated ashes have a very small particle size and are transported with the flue gas flow. Commonly, these fly ashes are removed by a filter (usually an electric precipitator) (Wiechmann et al., 2013; Outotec, 2016; Infraserf, 2018).

The content of phosphorus in these ashes is up to $20 \%$ by mass as $\mathrm{P}_{2} \mathrm{O}_{5}$ (the amount of phosphorous in this substance is $43.6 \%$ by mass, so finally up to $8.6 \%$ by mass as $\mathrm{P}$ in the ash) and is therefore much higher than in sewage sludge (Adam et al., 2009). The phosphorus contents obtainable in the sewage sludge ash are about 50 to $70 \%$ less than the phosphate contents of crude phosphate fertilizer or triple superphosphate, which is still high (Waida et al., 2010). However, during the combustion process the phosphorus is transferred into low-solubility mineral phases with low plant availability. It is therefore required to transfer the phosphate by means of a suitable thermochemical reaction to a plant-available form (Drissen, 2012). 


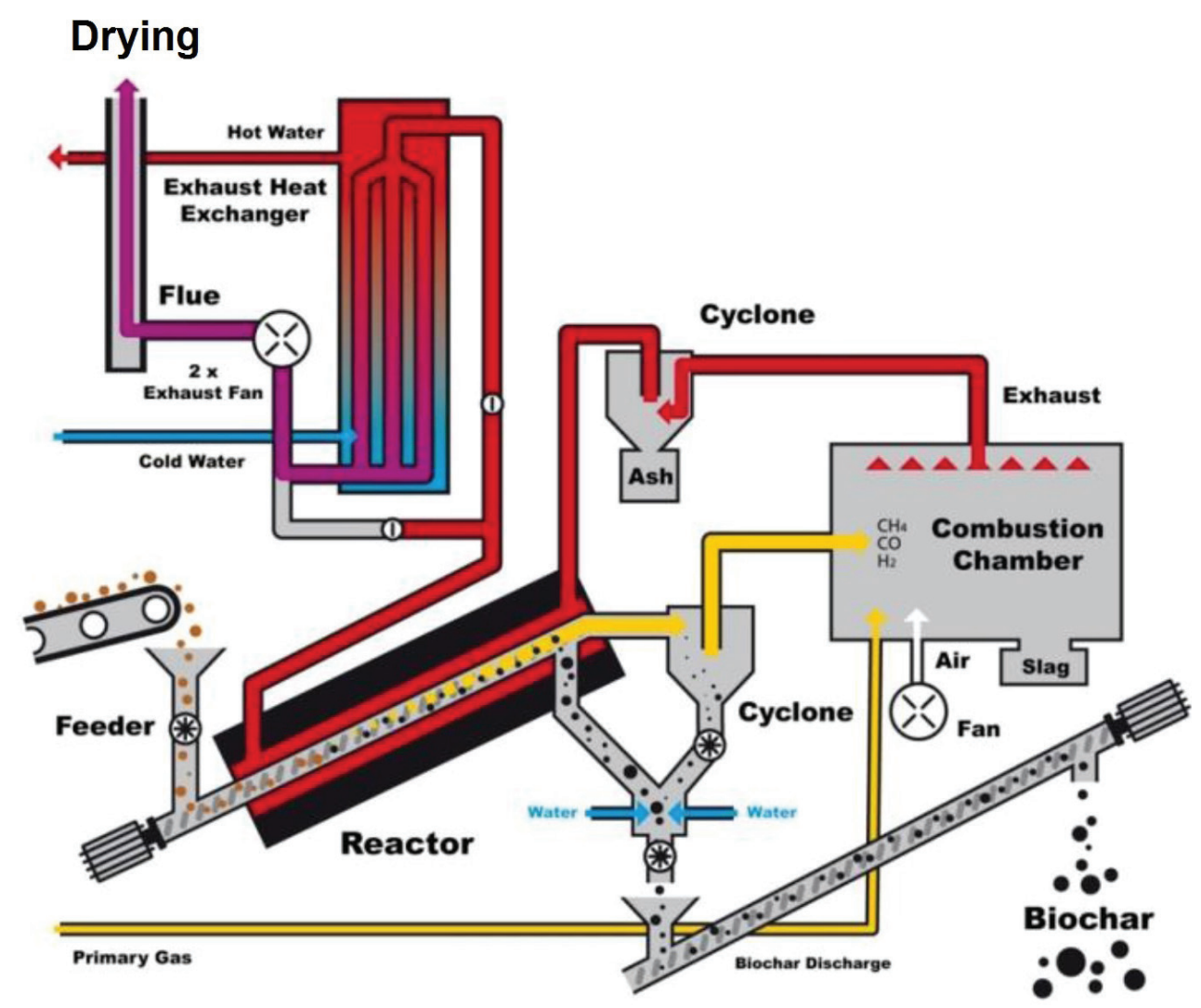

FIGURE 4: Pyrolysis process with production of bio-char (Greenlife, 2017).

After technical preparation (e.g. PASCH (Pinnekamp et al., 2010), RecoPhos (Weigand et al., 2013), EcoPhos (DeRuiter, 2014), LEACHPHOS (Buehler and Schlumberger, 2014), MEPHREC (Gruener and Reinmoeller, 2016) or Ash-Dec (Nowak et al., 2011), theoretically over $90 \%$ of phosphorus that is contained in sewage sludge can be recovered (Egle et al., 2016). Assuming $90 \%$ of the phosphorus contained in the wastewater in the sewage sludge is eliminated, a recycling potential of up to $80 \%$ of the phosphorus load in the inlet of the sewage treatment plant can be achieved.

\subsubsection{Gasification}

After sewage sludge gasification, phosphorus can also potentially be recovered from the ash (Gorazda et al., 2018). Recovery of nitrogen is not possible as it is diluted in the form of $\mathrm{N}_{2}$ in produced syngas (Winkler, 2012). At Kopf gasification plant (Balingen, Germany), it is reported that phosphorus out of the mineral granulate, produced from the slag, can be recovered (EPA, 2012).

\subsubsection{Pyrolysis}

With the application of the pyrolysis process it is possible to save nutrients by converting sewage sludge into a carbon-phosphorus fertilizer. A pyrolysis plant with a capacity of $4,000 \mathrm{Mg} / \mathrm{a}$ of dewatered sewage sludge (25\% ds) produces some $500 \mathrm{Mg} / \mathrm{a}$ of biochar (Greenlife, 2017). The most interesting property of the biochar is its resistance to biological and physical degradation when incorporated into soils, thus conferring other properties (e.g., nutrient and water retention, microbial activation, liming, and others) that improve soil functions over time periods from decades to centuries. Thus, biochar can be used in soil conditioning.

Depending on the nature of the sewage sludge feedstock, the nitrogen and calcium content in pyrolysis biochar allow for its consideration as a potential fertilizer. The investigations also show high phosphate content of biochar, which exceeds the minimum EU standard for phosphate fertilizers (CORDIS, 2017). However, the heavy metal content of biochar can limit its agricultural application depending on the national legal requirements.

\subsection{Market value of products/by-products}

\subsubsection{Incineration}

During the incineration process, sewage sludge is combusted and the energy is recovered as heat and electricity. These "products" are first of all used to cover the incineration plant's own consumption; the residuary amounts of energy can be sold. The fluidised bed material containing some small amount of ash has no market value but can be used in road construction for example, or to produce other construction materials. The residues from the flue gas cleaning can be cost-intensively disposed of or can also be cost-intensively stabilized and further used in the construction industry, e.g. for cement production, in the manufacture of building ceramics, or as a substitute for sand or cement in road construction (Smol et al., 2015).

Currently, the recovery of phosphorus out of fly ashes is even more expensive than the production of phosphorus out of phosphorus ores; the former is therefore not economically feasible. At the same time, a price increase is ex- 


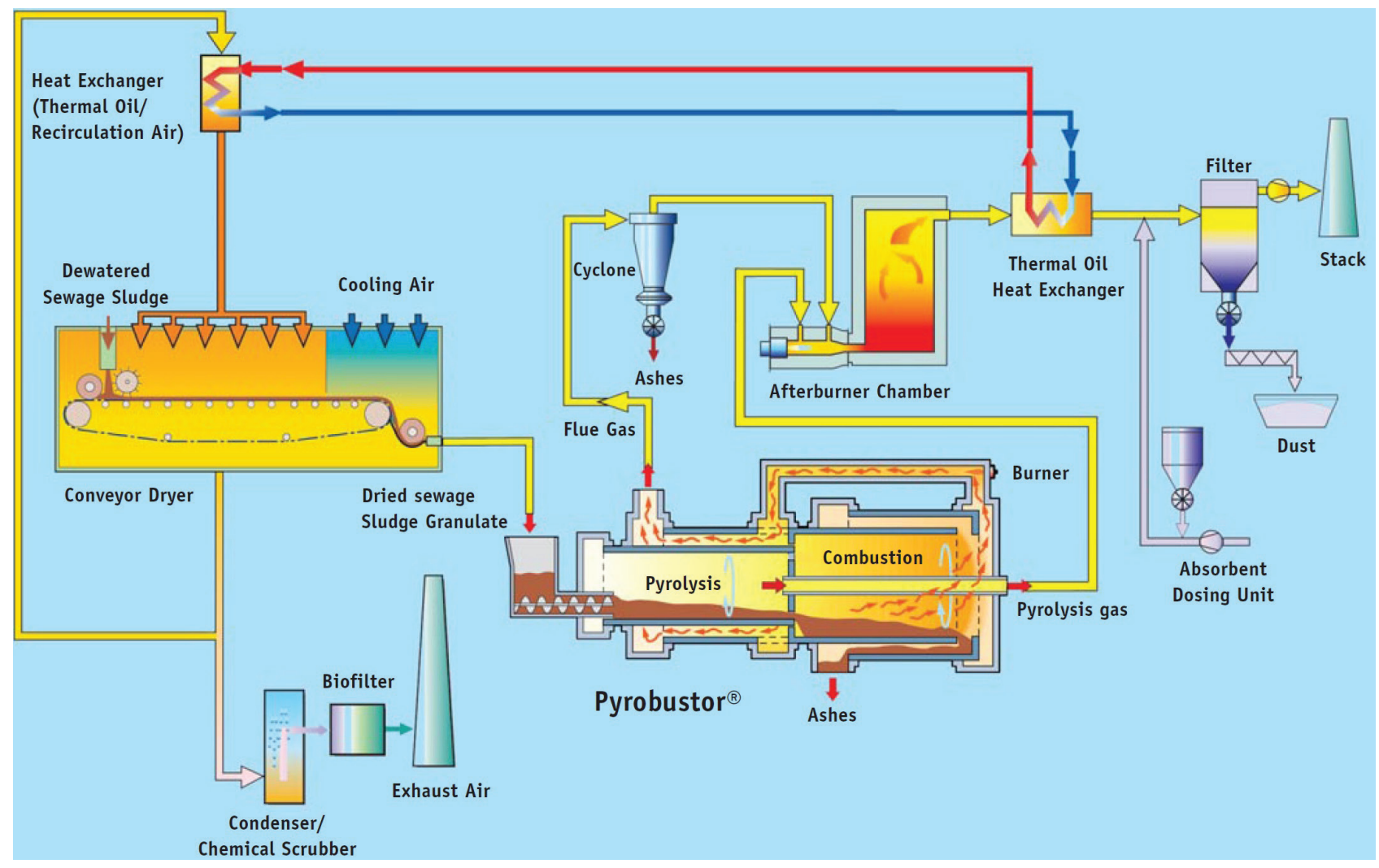

FIGURE 5: Pyrolysis process by Pyrobustor (EISENMANN, 2017).

pected for phosphorus from natural deposits in the future and a reduction of costs for phosphorus recovery (thanks to learning effects and up-scaling) out of sewage sludge (Cieślik and Konieczka, 2017; Guedes et al., 2014; Tan and Lagerkvist, 2011). This makes the ashes already valuable enough to landfill the material on separate sites in order to get it back when phosphorus recovery becomes economically feasible.

\subsubsection{Gasification}

The main useful product of sewage sludge gasification is syngas. Syngas can be directly used for the necessary thermal drying of sewage sludge to a dry substance between 75 and $90 \%$ (closed coupled gasification), or to generate electricity and heat in a gas turbine or a gas engine (two stage gasification). For utilization in gas turbines and gas engines, the syngas has to be treated (cleaned); for gas turbines the syngas also needs a minimum heating value of approx. 17.0 $\mathrm{MJ} / \mathrm{Nm}^{3}$ and needs to be pressurized. Usually, as compared to other types of fuel such as biogas or natural gas, the energy content of syngas is three to five times lower (Winkler, 2012).

A study in which a comparative analysis of the efficiency of sewage sludge gasification and pyrolysis was conducted shows that when the pyrolysis process is operated at relatively high temperatures $\left(>800^{\circ} \mathrm{C}\right)$, the obtained proportion of combustible gases $(78 \%)$ is even higher than the proportion after the gasifier (42\%). It was also determined that, relative to gasification, the pyrolysis process produces larger concentrations of gases with higher combustion en- thalpies and also includes a small quantity of ethane. The combination of these factors means that a syngas produced in the pyrolysis process has twice as much calorific value as the one after the gasifier (Mills, 2015).

Slag from a high temperature gasifier is non-leachable, non-hazardous and typically suitable for use in construction materials. For example, at Kopf gasification plant in Balingen, Germany, mineral granulate produced out of slag is used for asphalt and construction materials (EPA, 2012).

\subsubsection{Pyrolysis}

During pyrolysis, as a result of the heating of sewage sludge in an anoxic environment, a chemical decomposition of the organic component of sewage sludge takes place to form solid char containing pyrolytic carbon and mineral components. In addition, pyrolysis gases are generated, some of which are capable of condensing and forming a liquid fraction, while the remaining part is a combustible gas. Gaseous non-condensable pyrolysis products can be used in the thermal desorption process itself as a fuel to maintain the required temperature and the auto-thermal process. The condensed pyrolysis gas is an oily water-miscible liquid and is a fraction of hydrocarbons with a boiling point of $200-440^{\circ} \mathrm{C}$. It is known that hydrocarbons with a boiling point up to $400^{\circ} \mathrm{C}(\mathrm{C} 12-\mathrm{C} 22)$ are used as diesel or boiler fuel. This liquid phase does not contain toxic heavy metals, such as lead or mercury; the content of aromatic compounds (benzene, toluene, ethylbenzene, $\mathrm{n}$-xylene and o-xylene) does not exceed their concentrations in the fuel oil. The calorific value of a fuel containing 
hydrocarbons with a boiling point of $200-400^{\circ} \mathrm{C}$ is 35,000 $40,000 \mathrm{~kJ} / \mathrm{kg}$. Pyrolysis processes are typically operated to maximize the bio-oil yield. The energy potential of such biooil from condensed pyrolysis gases can be used for drying sewage sludge or for creating the necessary temperature for pyrolysis, which leads to a significant reduction in operating costs. Alternatively, this bio-oil can be upgraded to transportation fuel. The oil, once refined, can be stored and transported (Cao, 2011; Kim, 2008).

Solid char formed during pyrolysis is half composed of pyrolytic carbon. The significant content of pyrolytic carbon in solid char and the determination of the total porosity by moisture capacity allow one to assume that it has sorption properties. High hydrophobicity and sufficient sorbent oil capacity of the solid char mean it can be recommended as a sorbent for extracting oil and petroleum products from water and absorbing oil spilled on solid surfaces during accidental spills of petroleum products (Spinosa et al., 2011; Khodyashev et al., 2009).

An alternative application of the biochar generated out of sewage sludge pyrolysis is apparent from the phosphate content of the material, which is well above the minimum EU standard for phosphate fertilizers. Potential biochar fertilizer values are to be exploited also with regard to its nitrogen and calcium content, depending on the exact nature of the feedstock sewage sludge (CORDIS, 2017; Spinosa et al., 2011). The limitation of the agronomic properties of the biochar can be related to the heavy metal content of the product and should be thoroughly investigated in each particular case.

\subsection{Flexibility when applying the method}

\subsubsection{Incineration}

Incineration of sewage sludge in a fluidized bed is only possible under the precondition of a minimum heating value of $3,000-4,000 \mathrm{MJ} / \mathrm{Mg}$ wet substance (depending on the pre-heating temperature of the primary air) for reaching an auto-thermal combustion. Depending on the sewage sludge quality (pre-digested or not, degree of stabilisation, content of organics and carbon), the mechanically dewatered sewage sludge of usually $20-35 \%$ dry substance content has to be thermally dried to a minimum of $40 \%$ dry substance. If the incineration plant is situated near a sewage treatment plant or if the delivered sewage sludge is just mechanically dried, a thermal drying step has to be included in the treatment process. This thermal drying can be achieved with some extra effort by the energy recovered out of the incineration process (Franck J., 2015; Franck J. and Schroeder L., 2014; Franck J. and Schroeder L., 2015; Glatzer A. and Friedrich M., 2015).

A big disadvantage of the incineration process is low flexibility in terms of downscaling. The smallest plants have capacities of approx. 2,000 Mg ds/a (for approx. 70,000 people) with very high specific costs of more than 500 euros/Mg ds.

\subsubsection{Gasification}

There are only a small number of plants for sewage sludge mono-gasification worldwide because of a techni- cally highly demanding procedure, with high down times, which is not very efficient in terms of energy or costs. The syngas produced during the sewage sludge gasification contains combustible components; it enables the use of the syngas as a feedstock (through some reforming processes), or as a fuel. The composition of the main combustible components of the syngas $\left(\mathrm{H}_{2}\right.$ and $\left.\mathrm{CO}\right)$ that defines its lower heating value (LHV) depends on the amount of the air supplied to the reactor. The optimum value of the air ratio $(\lambda)$ equal to 0.18 leads to LHV taking its maximum value and thus favors gasification resulting in combustible gases, rather than the case of complete combustion with an air supply that mainly produces $\mathrm{CO}_{2}$ (Werle, 2016).

Depending on the technology used (fixed bed updraft or downdraft gasifier, fluidized bed gasifier), the dry matter content of the feedstock for gasification should be $45-50 \%$, more than $80-85 \%$ correspondingly (Winkler, 2012). Usually, water content in the sewage sludge treated with the gasifier should be between 10-20\%.

Both undigested and digested sewage sludge can be treated using the gasification method, but undigested sludge is preferable as it results in higher energy content of the produced syngas (Winkler, 2012).

The scale of a gasification plant strongly depends on the type of the gasifier used and the ranges from small scales of $5 \mathrm{~kW}-20 \mathrm{MW}$ for downdraft fixed bed gasifiers up to $100 \mathrm{MW}$ for circulating fluidized bed gasifiers (EPA, 2012). Economic feasibility of a gasification plant depends electricity tariffs among other factors; some calculation shows that a gasification plant becomes economically feasible at a plant capacity of about $0.093 \mathrm{~m}^{3} / \mathrm{s}$ (raw sewage flows) (Lumley et al., 2014).

\subsubsection{Pyrolysis}

During the pyrolysis of sewage sludge, (depending on feedstock, pyrolysis temperature, pressure, retention time and additives, and different amounts of gases) liquids and solids are produced. For pyrolysis, the mechanically dewatered sludge has to be thermally dried to a dry substance between 65 and $90 \%$.

Pyrolysis technology applied to sewage sludge is more flexible in terms of downscaling than incineration or gasification. Pyrolysis plants can be compact and used to treat and dispose of the sewage sludge produced in small municipalities (with fewer than 10,000 inhabitants). The sludge load for such a compact plant can be up to $200 \mathrm{Mg}$ $\mathrm{ds} / \mathrm{a}$ with specific cost of 400-650 euros/Mg ds (CORDIS, 2017).

\section{RESULTS AND DISCUSSION}

A comparative analysis of three se wage sludge thermal treatment methods in the context of a circular economy has been carried out using a criterion model consisting of five criteria. To make the final evaluation, the results of the analysis were aggregated in Table 3.

The costs of treatment in the cases of incineration and gasification of sewage sludge strongly depend on the scale of the plant; downscaling makes sense only if pyrolysis technology is applied. If it is possible to use a large 
TABLE 3: Results of the comparative analysis of sewage sludge thermal treatment methods on the basis of the criterion model.

\begin{tabular}{|c|c|c|c|c|c|c|c|c|c|c|c|c|}
\hline \multirow[t]{2}{*}{ Criteria } & \multicolumn{2}{|c|}{$\begin{array}{l}\text { 1. Cost of } \\
\text { treatment }\end{array}$} & \multicolumn{3}{|c|}{$\begin{array}{l}\text { 2. Energy } \\
\text { efficiency }\end{array}$} & \multirow[t]{2}{*}{$\begin{array}{l}\text { 3. Nutrient } \\
\text { recovery }\end{array}$} & \multicolumn{3}{|c|}{$\begin{array}{l}\text { 4. Product market } \\
\text { value }\end{array}$} & \multicolumn{3}{|c|}{ 5. Flexibility } \\
\hline & $\begin{array}{c}\text { Plant } \\
\text { capacity, } \\
\text { Mg DS/a }\end{array}$ & $\begin{array}{c}\text { Specific } \\
\text { costs, } \\
\text { euros/Mg } \\
\text { DS }\end{array}$ & $\begin{array}{c}\text { Plant } \\
\text { capacity, } \\
\text { Mg DS/a }\end{array}$ & $\begin{array}{c}\text { Produced } \\
\text { electricity, } \\
\text { MW }\end{array}$ & $\begin{array}{l}\text { Delivered } \\
\text { electricity, } \\
\text { MW }\end{array}$ & & $\begin{array}{l}\text { Plant's } \\
\text { own } \\
\text { consump- } \\
\text { tion }\end{array}$ & $\begin{array}{c}\text { Products } \\
\text { with no } \\
\text { market } \\
\text { value }\end{array}$ & $\begin{array}{l}\text { Valuable } \\
\text { products }\end{array}$ & $\begin{array}{l}\text { Feed- } \\
\text { stock dry } \\
\text { matter } \\
\text { content }\end{array}$ & $\begin{array}{l}\text { Down- } \\
\text { scaling }\end{array}$ & $\begin{array}{l}\text { Other } \\
\text { consider- } \\
\text { ations }\end{array}$ \\
\hline \multirow{3}{*}{ 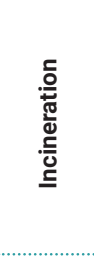 } & 2,000 & 510 & 2,000 & $\mathrm{~N} / \mathrm{a}^{*}$ & $\mathrm{~N} / \mathrm{a}$ & \multirow{3}{*}{$\begin{array}{l}\text { Potentially } \\
\text { up to } 80 \% \text { of } \\
\text { phosphorus } \\
\text { load in the } \\
\text { sewage } \\
\text { sludge can } \\
\text { be recovered } \\
\text { from the fly } \\
\text { ashes }\end{array}$} & \multirow[b]{3}{*}{$\begin{array}{l}\text { Heat and } \\
\text { electricity }\end{array}$} & \multirow{3}{*}{$\begin{array}{l}\text { Use of } \\
\text { ash in } \\
\text { road } \\
\text { construc- } \\
\text { tion }\end{array}$} & \multirow[b]{3}{*}{ Electricity } & \multirow[b]{3}{*}{$\begin{array}{l}\text { Approx. } \\
40 \%\end{array}$} & \multirow[b]{3}{*}{ Limited } & \multirow[b]{3}{*}{ - } \\
\hline & 4,000 & 487 & 4,000 & $\mathrm{~N} / \mathrm{a}$ & $\mathrm{N} / \mathrm{a}$ & & & & & & & \\
\hline & 35,000 & 157 & 35,000 & 4.4 & 0.4 & & & & & & & \\
\hline 冚 & \multicolumn{2}{|c|}{$\begin{array}{l}\text { No data available; } \\
\text { the most expensive } \\
\text { method according to } \\
\text { the general overview } \\
\text { of literature }\end{array}$} & 4,500 & 0.6 & $\begin{array}{c}\mathrm{N} / \mathrm{a} \\
\text { (and also } \\
0.8 \mathrm{MW} \\
\text { of heat is } \\
\text { pro- } \\
\text { duced) }\end{array}$ & $\begin{array}{l}\text { Examples of } \\
\text { phosphorus } \\
\text { recovery from } \\
\text { the slag; } \\
\text { potentially } \\
\text { possible } \\
\text { phosphorus } \\
\text { recovery from } \\
\text { the ash }\end{array}$ & $\begin{array}{l}\text { Heat and } \\
\text { electricity }\end{array}$ & $\begin{array}{l}\text { Use of } \\
\text { slag for } \\
\text { asphalt } \\
\text { and con- } \\
\text { struction } \\
\text { materials }\end{array}$ & Syngas & $80-90 \%$ & $\begin{array}{l}\text { Hardly } \\
\text { possible }\end{array}$ & $\begin{array}{l}\text { Techni- } \\
\text { cally com- } \\
\text { plicated } \\
\text { process }\end{array}$ \\
\hline \multirow[b]{2}{*}{$\frac{\frac{0}{n}}{\frac{2}{0}}$} & 200 & $400-650$ & 1,000 & $\mathrm{~N} / \mathrm{a}$ & -0.0075 & \multirow[b]{2}{*}{$\begin{array}{l}\text { Application } \\
\text { of biochar for } \\
\text { soil condi- } \\
\text { tioning or as } \\
\text { a fertilizer }\end{array}$} & \multirow[b]{2}{*}{$\begin{array}{l}\text { Heat and } \\
\text { electricity }\end{array}$} & \multirow[b]{2}{*}{ Sulfur } & \multirow[b]{2}{*}{$\begin{array}{l}\text { Bio-oil; } \\
\text { Char for } \\
\text { the pro- } \\
\text { duction of } \\
\text { sorbent } \\
\text { and/or as } \\
\text { soil con- } \\
\text { ditioner; } \\
\text { Syngas }\end{array}$} & \multirow[b]{2}{*}{$65-90 \%$} & \multirow[b]{2}{*}{ Possible } & \multirow[b]{2}{*}{ - } \\
\hline & & 183 & 4,000 & $\mathrm{~N} / \mathrm{a}$ & $\begin{array}{l}-0.1 \\
\text { (and } \\
\text { also }-1.0 \\
\text { MW of } \\
\text { thermal } \\
\text { energy) }\end{array}$ & & & & & & & \\
\hline
\end{tabular}

* N/a: not applicable

capacity plant (e.g., in a large city with a population of more than a million people), incineration is the most preferable technology in terms of costs. If it is necessary to use a plant with a small capacity, pyrolysis is the most appropriate technology for thermal treatment of sewage sludge.

When processing sewage sludge using each of the three technologies considered, some heat and electricity are generated; it can be utilized in the treatment process itself or delivered to external consumers. The data obtained when comparing the technologies on the basis of the energy balance criterion made it possible to identify a technology generating excess electricity that can be put on the electricity market. Pyrolysis of sewage sludge in this respect has negative characteristics: heat and electricity produced are utilized completely in the plant for drying sewage sludge and maintaining the auto-thermal process. Additionally, some extra energy input is needed to maintain the overall process from the drying of mechanically dewatered sewage sludge to the final treatment of flue gases. The energy generated during the gasification of sewage sludge is also fully utilized in the plant itself, and no surplus energy can be exported from the process. Export of a certain amount of electricity is only possible with the use of sewage sludge incineration, provided that the plant has a sufficiently high capacity. The smaller incineration plants produce no electricity but can at least cover the heat needed for drying sewage sludge with the produced energy.

All three sewage sludge thermal treatment technologies considered are quite inefficient in terms of the possibility for nutrient recovery. The most promising method under this evaluation criterion is incineration, where fly ash can be used as a source of phosphorus, subject to the appearance of appropriately efficient and economically feasible technologies for phosphorus recovery out of the ash. The coke produced during the pyrolysis of sewage sludge can be used directly as a fertilizer or as a soil conditioner, as long as the level of heavy metals in the coke is acceptable. There are some data on the extraction of phosphorus out of gasification slag (Gorazda, 2018).

When evaluating the criterion of the market value of products and by-products of sewage sludge thermal treatment methods, three types of such products were considered: products used in the treatment process itself, environmentally safe products with zero market value and products with market value. For all the three technologies analyzed, the first type of products includes heat and electricity, which are used in the thermal treatment process itself and thus allow savings on primary energy resources. If sewage sludge is incinerated at a high-capacity plant, it may create some surplus electricity that can be put on the market and thus become a market product. The main marketable product of gasification of sewage sludge is syngas. Its calorific value is low in comparison with other types of fuel; also, syngas has to be treated (cleaned) and pressurized in order to be used in gas turbines and gas engines. In the pyrolysis of sewage sludge, syngas is also generated. In addition, the condensable gas fraction has high caloric value and can be used as a boiler fuel or fuel oil. Biochar produced during sewage sludge pyrolysis shows the presence of sorption properties, which, taking into account its hydrophobicity makes it possible to use biochar as a sorbent in the liquidation of oil spills. The coke 
can also be used as a fertilizer or soil conditioner due to the high content and plant availability of phosphorus, nitrogen and calcium.

The main preconditions that determine the application of a particular sewage sludge thermal treatment method are the moisture content in the feedstock and the possibility of using a low-capacity plant. Incineration is less demanding on high contents of dry substance in the sewage sludge than gasification and pyrolysis. The gasification method has not been widely used in the world due to the technical complexity of maintaining the process. The downscaling capabilities are limited when using incineration and gasification methods; the pyrolysis method can be applied at a level of cost comparable with that of low capacity installations.

Ultimately, the decision on the preferability of a certain method of thermal sewage sludge treatment depends on which of the presented criteria are of the highest importance for the decision maker. If all the criteria are equally relevant (e.g., there is a state circular economy development program, which includes subsidies for the implementation of appropriate technologies), the incineration method is actually the most optimal, taking into account the principles of the circular economy.

\section{CONCLUSIONS}

The feasibility of using thermal methods for the treatment of large-tonnage waste generated in the process of traditional municipal wastewater treatment, namely sewage sludge, has been analyzed in the context of a circular economy. The concept of circular economy has been studied, and its main characteristics with regard to sewage sludge treatment have been identified, including the exclusion of waste landfilling, pollutant emission and hazardous substance accumulation, reuse/recycle/energy recovery from waste, reduced input of primary natural resources, and application of systems thinking.

Comparative analysis of three sewage sludge thermal treatment methods (incineration, gasification and pyrolysis) has been performed on the basis of the developed criterion model. The analysis has shown that the most advantageous method for the criteria of cost of treatment, energy efficiency, nutrient recovery and flexibility in terms of feedstock dry matter content is incineration, whereas the most preferable method for the criteria of product market value and flexibility in terms of downscaling is pyrolysis. This makes incineration the most preferable sewage sludge thermal treatment method in the context of a circular economy within the framework of the developed criterion model, based on the assumption that all the criteria are of equal importance.

The results of this study could be used for establishing an effective sewage sludge management system at a regional or state level. In further studies, the authors plan to carry out a quantitative comparison of material flows and to develop corresponding diagrams for each of the three considered thermal treatment technologies. In addition, it is planned to assess the costs of sewage sludge treatment using thermal treatment methods taking into account the revenues from the sale of generated market products and by-products, as well as the costs incurred when disposing sewage sludge at landfills.

\section{REFERENCES}

Adam C., Peplinski B., Michaelins M., Kley G. and Simon F.-G. (2009) Thermochemical treatment of sewage sludge ashes for phosphorus recovery. In Waste Management 29 (2009) 1122-1128.

Alvarenga, P., Mourinha, C., Farto, M., Santos, T., Palma, P., Sengo, J., Morais, M.C., Cunha-Queda, C., 2015. Sewage sludge, compost and other representative organic wastes as agricultural soil amendments: Benefits versus limiting factors. Waste Manag. 40, 44-52. doi:10.1016/j.wasman.2015.01.027.

Brunner P. and Rechenberger H. (2015). Waste to energy - key element for sustainable waste management. In Waste Management 37 (2015) 3-12.

Buehler F. and Schlumberger S. (2014) Phosphormining aus Klärschlammasche - Nasschemische Extraktion - LEACHPHOS eine Lösung die funktioniert. Presentation 21.01.2014.

Cao Y., Shan S., 2011. Sustainable approach to energy recovery from sewage sludge. 2nd International Conference on Environmental Engineering and Applications IPCBEE vol.17 (2011).

Cieślik, B., Konieczka, P., 2017. A review of phosphorus recovery methods at various steps of wastewater treatment and sewage sludge management. The concept of "no solid waste generation" and analytical methods. J. Clean. Prod. doi:10.1016/j.jclepro.2016.11.116.

CORDIS (2017). Final Report Summary - PYROCHAR (PYROlysis based process to convert small WWTP sewage sludge into useful bioCHAR).

Deng W., Li X., Yan J., Wang F., Chi Y., Cen K. (2011). Moisture distribution in sludges based on different testing methods. J. Environ. Sci., vol. 23, n. 5, 875-880.

DeRuiter R., 2014. The EcoPhos Technology to close the P cycle and safeguard the world's food chain. Presentation at Workshop Abwasser - Phosphor - Dünger. 28-29 (January 2014. Berlin).

Directive 2008/98/EC of the European Parliament and the Council of 19 November 2008 on waste and repealing certain Directives (2008). Official Journal of the European Union, L 312, 3-30.

Drissen P. (2012). Ressourceneffiziente Herstellung von Dünger aus Stahlwerksschlacke und P205-haltigen Reststoffen, FEhs - Institut für Baustoffforschung e.V., Report 19/2, Duisburg.

Egle L., Rechberger H., Krmpe J. and Zessner M. (2016). Phosphorus recovery from municipal wastewater: An integrated comparative technological, environmental and economic assessment of $P$ recovery technologies. in Science of the Total Environment 571 (2016) 522-542.

EISENMANN Anlagenbau GmbH \& Co.KG Environmental Technology (2017). Thermal treatment of sewage sludge in the Pyrobustor.

Ellen McArthur Foundation (2013). Towards the Circular Economy: Economic and business rationale for an accelerated transition.

EPA, U.S. (2012). Technology Assessment Report: Aqueous Sludge Gasification. U.S. Environmental Protection Energy.

Eriksson E., Christensen N., Ejbye Schmidt J., Ledin A. (2007). Potential priority pollutants in sewage sludge. In Desalination 226 (2008) 371-388.

European Commission (2015). Closing the loop - An EU action plan for the Circular Economy.

Eurostat (2013). Sewage sludge disposal from urban wastewater treatment, by type of treatment.

Frank J. (2015). Monoverbrennung von Klärschlamm - Ab welcher Größe ist das realistisch? Presentation at Fach-Seminar zum Thema Abwasserreinigung und Klärschlamm Neue Erkenntnisse aus Forschung und Praxis im Schloss Etelsen, 19th of march 2015.

Franck J., Schroeder, L. (2014). Zukunftsfähigkeit kleinerer Anlagen der thermischen Klärschlammverwertung, Presentation at Klärschlammbehandlung - eine Veranstaltung des VDI-Wissensforums, 17.09.2014.

Franck J. And Schroeder L. (2015). Zukunftsfähigkeit kleiner Klärschlammverbrennungsanlagen. In Energie aus Abfall, Band 12, ISBN: 978-3-944310-18-3, TK Verlag, Neuruppin, Januar 2015.

Glatzer A., Fiedrich M. (2015). Klärschlamm-Monoverbrennung wirtschaftliche und technische Grenzen, presentation at 1. DWANetzwerktag Klärschlammnetzwerk Nord-Ost 9.9.2015, Berlin-Steglitz. 
Gorazda K., Tarko B., Werle S. and Wzorek Z. (2018). Sewage sludge as a fuel and raw material for phosphorus recovery: Combined process of gasification and $\mathrm{P}$ extraction. In Waste Management 73 (2018) 404-415.

Greenlife Ressourcen $\mathrm{GmbH}$ (2017). Recycling of sewage sludges: pyrolysis.

Gruener and Reinmoeller (2016). Phosphorrecycling mit dem Nephrec-Verfahren - Betriebserfahrungen. Presentation at the Berliner Abfallwirtschafts- und Energiekonferenz, Berlin, 31.01.2016.

Guedes, P., Couto, N., Ottosen, L.M., Ribeiro, A.B., 2014. Phosphorus recovery from sewage sludge ash through an electrodialytic process. Waste Manag. 34, 886-892. doi:10.1016/j.wasman.2014.02.021.

Houillon, G., Jolliet, O., 2005. Life cycle assessment of processes for the treatment of wastewater urban sludge: Energy and global warming analysis, in: Journal of Cleaner Production. Elsevier, pp. 287-299. doi:10.1016/j.jclepro.2004.02.022.

Infraserv (2018). Sewage Sludge Incineration: Safe and Environmentally Responsible, brochure.

IPPC (2006). Reference Document on the Best Available Techniques for Waste Incineration. The European IPPC Bureau.

Kim Y., Parker W., 2008. Bioresource Technology 99 (2008) 1409-1416. doi:10.1016/j.biortech.2007.01.056

Khodyashev M.B., Glushankova I.S., Dyakov M.S. (2009). Methodological approaches to the development of a technology of thermal treatment of solid oil-containing wastes of oil refineries (Методологические подходы к разработке технологии термической утилизации твердых нефтесодержащих отходов нефтеперерабатывающих предприятий). Ekologiya i promyshlennost Rossii, November 2009, 2-5.

Li, R., Teng, W., Li, Y., Wang, W., Cui, R., Yang, T., 2017. Potential recovery of phosphorus during the fluidized bed incineration of sewage sludge. J. Clean. Prod. 140, 964-970. doi:10.1016/j.jclepro.2016.06.177.

Lumley N.P.G., Ramey D.F., Prieto A.L., Braun R.J., Cath T.Y., Porter J.M. (2014). Techno-economic analysis of wastewater sludge gasification: A decentralized urban perspective. Bioresource Technol. 161, 385-394.

Lundin M., Olofsson M., Pettersson G.J., Zetterlund H., 2004. Environmental and economic assessment of sewage sludge handling options, in: Resources, Conservation and Recycling 41, 255-278. doi:10.1016/j.resconrec.2003.10.006.

Mills N. (2015). Unlocking the Full Energy Potential of Sewage Sludge. University of Surrey.

Morgano M.T., Leibold H., Richter F., Seifert H., Stapf D. (2016). Screw Pyrolysis of Sewage Sludge: A Techno-economic Analysis, Presentation at Symposium on Thermal and Catalytic Sciences for Biofuels and Biobased Products, November 1-4, 2016, The Friday Center, University of North Carolina, Chapel Hill.

Neumann U., Tittesz R. (2011). Der Pyrobustor - zwei Praxisbeispiele zur Klärschlammpyrolyse. In Energie aus Abfall Band 8, ISBN 978-3-935317-60-3,TK-Verlag, Neuruppin, 2011.

Nowak B., Perutka L., Aschenbrenner P., Kraus P., Rechberger H., Winter F., (2011). Limitations for heavy metal release during thermo-chemical treatment of sewage sludge ash. in Waste Manag. 31 (6), 1285-1291.

Outotec (2016). Sustainable Sewage Sludge Incineration for Zürich Canton. Outotec SEAP Costomer eNewsletter 1/2016

ÖWAV (2013). ÖWAV - Österreichischer Wasser- und Abfallwirtschaftsverband, 2013. Energetische Wirkungsgrade von Abfallverbrennungsanlagen, ÖWAV- Regelblatt 519. Austrian Standards plus Publishing, 1020 Vienna, Heinestraße 2.
Pavlík Z., Fort J., Zalesk M., Milena Pavlíkova M., Trník A., Medved I., Keppert M., Koutsoukos P., Cerný R. (2016). Energy-efficient thermal treatment of sewage sludge for its application in blended cements in Journal of Cleaner Production 112 (2016) 409-419.

Pinnekamp J., Montag D., Hell J., Gajic D., Rath W., Dittrich C., Pfennig A., Kröckel J., Abdellatif T., Dott W., Zimmermann J., Doetsch P., van Norden H., Grömping M. And Seyfried a. (2010). Rueckgewinnung von Pflanzennährstoffen, insbesondere Phosphor aus der Asche von Klaerschlamm, Schlussbericht, Mai 2010.

Raheem A., Singh Sikarwar V., He J., Dastyar W., Dionysiou D., Wang W. Zhao M. (2018). Opportunities and challenges in sustainable treatment and resource reuse of sewage sludge: A review. In Chemical Engineering Journal 337 (2018) 616-641.

Smol, M., Kulczycka, J., Henclik, A., Gorazda, K., Wzorek, Z., 2015. The possible use of sewage sludge ash (SSA) in the construction industry as a way towards a circular economy. J. Clean. Prod. doi:10.1016/j.jclepro.2015.02.051.

Spinosa L., Ayol A., Baudez J.-C., Canziani R., Jenicek P., Leonard A., Rulkens W., Xu G., van Dijk L. (2011). Sustainable and Innovative Solutions for Sewage Sludge Management. Water, vol. 3, 702-717.

Stasta, P., Boran, J., Bebar, L., Stehlik, P., Oral, J., 2006. Thermal processing of sewage sludge. Appl. Therm. Eng. 26, 1420-1426. doi:10.1016/j.applthermaleng.2005.05.030.

Sülzle Kopf Anlagenbau GmbH (2017). SynGas solutions.

Tan, Z., Lagerkvist, A., 2011. Phosphorus recovery from the biomass ash: A review. Renew. Sustain. Energy Rev. doi:10.1016/j. rser.2011.05.016.

Uggetti, E., Llorens, E., Pedescoll, A., Ferrer, I., Castellnou, R., García, J., 2009. Sludge dewatering and stabilization in drying reed beds: Characterization of three full-scale systems in Catalonia, Spain. Bioresour. Technol. 100, 3882-3890. doi:10.1016/J. BIORTECH.2009.03.047.

UN-HABITAT (2008). Global atlas on excreta, wastewater sludge, and biosolids management: moving forward the sustainable and welcome use of a global resource: LeBlanc, Matthews, Richard (Eds).

Vadenbo, C., Guillén-Gosálbez, G., Saner, D., Hellweg, S., 2014. Multi-objective optimization of waste and resource management in industrial networks - Part II: Model application to the treatment of sewage sludge. Resour. Conserv. Recycl. 89, 41-51. doi:10.1016/j. resconrec.2014.05.009.

Valderrama, C., Granados, R., Cortina, J.L., Gasol, C.M., Guillem, M., Josa, A., 2013. Comparative LCA of sewage sludge valorisation as both fuel and raw material substitute in clinker production. J. Clean. Prod. 51, 205-213. doi:10.1016/j.jclepro.2013.01.026.

Waida C., Weinfurtner K., Gäth S.A. (2010). Bewertung verschiedener Sekundärphosphate aus Abwasser, Klärschlamm und Klärschlammasche, In: 43. Essener Tagung für Wasser- und Abfallwirtschaft, GWA, Heft 220, S. 39/1-39/12, RWTH Aachen, Aachen.

Weigand H., Bertau M., Hübner W., Bohndick F. and Bruckert, A. (2013). RecoPhos: full-scale fertilizer production from sewage sludge ash. Waste Manag. 33 (3), 540-544.

Werle S. (2016). Sewage sludge gasification process for clean and sustainable environment. Renew. Energy Environ. Sustain. 1, 35.

Wiechmann B., Dienemann C., Kabbe C., Brandt S., Vogel I., Roskosch A. (2013). Sewage sludge management in Germany.

Winkler M.J. (2012). Gasification of Sludge and Biosolids - A Review of Technology Fundamentals and the Current Commercial Status, presentation at the PNCWA 2012, on October 24th 2012, Boise, Idaho. 